\section{Commentary: What switch, to switch or not to switch: That is the question!}

\author{
Minoo N. Kavarana, MD
}

As predicted by pioneering surgeon Ake Senning in his response to an editorial lauding the success of his physiological correction of D-transposition of the great arteries (D-TGA), the anatomic arterial switch operation is now the gold standard for the surgical correction of D-TGA and the atrial inversion operation is performed infrequently. ${ }^{1}$ However, atrial inversion procedures are currently experiencing a renaissance in children with congenitally corrected transposition (C-CTGA) as part of a double-switch operation and in children with D-TGA who present late. ${ }^{2}$

The early technically complex Senning operation ${ }^{3}$ made way for the technically less demanding Mustard operation using a large prosthetic patch. ${ }^{4}$ However, an increased incidence of baffle obstruction, leaks, and inferior late outcomes in smaller children related to the larger amount of prosthetic material and therefore less growth potential with the Mustard procedure resulted in the pendulum swinging back toward the Senning procedure. ${ }^{5}$ Over time, modifications to the original atrial inversion operation with the Shumaker in situ pericardial well ${ }^{6}$ and hemiMustard one-and-a-half ventricle repair ${ }^{7}$ allowed for wider application of the atrial switch, particularly in patients with difficult anatomy, such as dextrocardia, situs inversus, and small right ventricular volume.

A small subset of patients who have undergone an atrial switch operation may present with right ventricular

\footnotetext{
From the Section of Pediatric Cardiothoracic Surgery, Medical University of South Carolina, Charleston, SC.

Disclosures: The author reported no conflicts of interest.

The Journal policy requires editors and reviewers to disclose conflicts of interest and to decline handling or reviewing manuscripts for which they may have a conflict of interest. The editors and reviewers of this article have no conflicts of interest.

Received for publication Aug 27, 2020; revisions received Aug 27, 2020; accepted for publication Aug 28, 2020; available ahead of print Sept 18, 2020.

Address for reprints: Minoo N. Kavarana, MD, FACS, Section of Pediatric Cardiothoracic Surgery, Medical University of South Carolina, 10 McClennon Banks Drive, SJCH 2190/MSC 918, Charleston, SC 29425 (E-mail: kavarana@musc.edu). JTCVS Techniques 2020;4:227-8

2666-2507

Copyright (C) 2020 The Authors. Published by Elsevier Inc. on behalf of The American Association for Thoracic Surgery. This is an open access article under the CC BY-NCND license (http://creativecommons.org/licenses/by-nc-nd/4.0/).

https://doi.org/10.1016/j.xjtc.2020.08.079
}

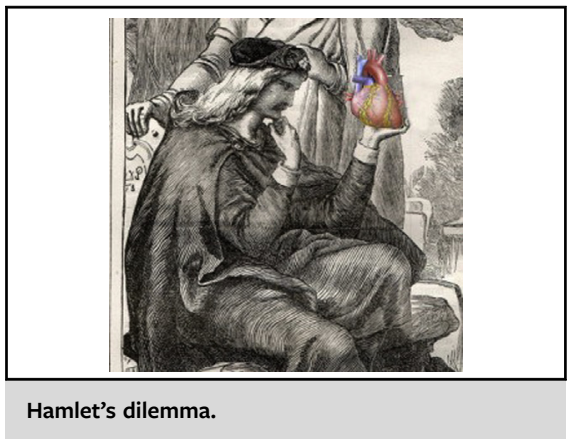

\begin{abstract}
CENTRAL MESSAGE
In patients presenting late with

D-transposition of the great arteries and total anomalous pulmonary venous return, a modified Senning procedure provides excellent physiological correction.
\end{abstract}

dysfunction. For these patients, left ventricular retraining by way of pulmonary artery banding followed by a late arterial switch has been suggested as an alternative to heart transplantation.

In this issue of the Journal, Mishra and colleagues 9 describe the successful use of the Shumaker modification of the Senning procedure with concomitant repair of total anomalous venous return (TAPVR) in 3 patients with DTGA and TAPVR that presented late. Important technical points (some of which are better appreciated in the accompanying video) included are that atrial septal flap advancement to divert pulmonary venous return is not required with TAPVR. Furthermore, only the rightward aspect (leftward in cases of situs inversus) of the pulmonary venous confluence should be dissected and opened with excision of the anterior wall. The in-situ pericardial well provides a larger surface area to account for unusual anatomic variants where the atrial free wall surface area is often lacking and may compromise the systemic and pulmonary venous baffles. The extensive unroofing of the coronary sinus that the authors describe is an important step that avoids the creation of a ridge with potential obstruction of the inferior vena cava end of the systemic venous baffle. Unroofing also allows diversion of coronary sinus return to the systemic venous circulation, which is useful when a left superior vena cava is present, allows more space to suture away from the atrioventricular node in the triangle of Koch 
(less relevant in C-CTGA), and permits future coronary sinus lead placement.

The authors' experience highlights the significance of revisiting the technical pearls, pitfalls, and lessons learned with the atrial inversion techniques, which although performed infrequently today, remain an important part of the congenital heart surgeon's armamentarium.

\section{References}

1. Bove EL. Senning's procedure for transposition of the great arteries. Ann Surg. 1987;43:678-80.

2. Konstantinov IE, Alexi-Meskishvili VV, Williams WG, Freedom RM, Van Praagh R. Atrial switch operation: past, present, and future. Ann Thorac Surg. 2004; $77: 2250-8$.

3. Senning A. Surgical correction of transposition of the great vessels. Surgery. 1959; 45:966-80.
4. Mustard WT, Chute AL, Keith JD, Sirek A, Rowe RD, Vlad P. The surgical approach to transposition of the great vessels with extracorporeal circuit. Surgery. 1954;36:39-51.

5. Quaegebeur JM, Rohmer J, Brom AG. Revival of the Senning operation in the treatment of transposition of the great arteries. Thorax. 1977;32:517-24.

6. Shumaker HB. A new operation for transposition of the great vessels. Surgery. 1961;49:773-7.

7. Malhotra SP, Reddy VM, Qiu M, Pirolli TJ, Barboza L, Reinhartz O, et al. The hemi-Mustard/bidirectional Glenn atrial switch procedure in the double-switch operation for congenitally corrected transposition of the great arteries: rationale and midterm results. J Thorac Cardiovasc Surg. 2011; $141: 162-70$.

8. Watanabe N, Mainwaring RD, Carrillo SA, Lui GK, Reddy VM, Hanley FL. Left ventricular retraining and late arterial switch for D-transposition of the great arteries. Ann Thorac Surg. 2015;99: 1655-63.

9. Mishra A, Garg P, Agarwal V, Rana Y. Transposition of great arteries with total anomalous pulmonary venous connection: a modified Senning procedure for late presentation. J Thorac Cardiovasc Surg Tech. 2020;4:223-6. 